\title{
Looking for an Oasis of Support: Greece and the Gulf states
}

\section{Asteris Huliaras and Sophia Kalantzakos}

GreeSE Paper No.96

Hellenic Observatory Papers on Greece and Southeast Europe

\section{JANUARY 2016}




\section{TABLE OF CONTENTS}

ABSTRACT

iii

1. Introduction_____ 1

2. Strategic Challenges in the Gulf ___ 3

3. The EU and the Gulf ___ 8

4. Greece and the GCC ___ 13

5. From security to economics ___ 17

6. Conclusions __ 30

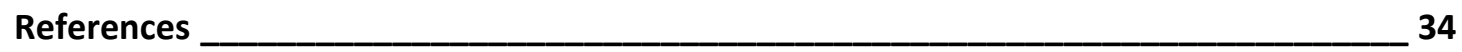

Interviews______ 41 


\title{
Looking for an Oasis of Support: Greece and the Gulf states
}

\author{
Asteris Huliaras ${ }^{\#}$ and Sophia Kalantzakos*
}

\section{ABSTRACT}

This paper examines Greece's relations with the Gulf Cooperation Council [GCC] countries: Bahrain, Kuwait, Oman, Qatar, Saudi Arabia and the United Arab Emirates. Greek-Arab ties have a long history that goes back to 1947, when Greece voted against the partition of Palestine in the UN General Assembly. In the post-1974 era, these relations have been strengthened, reflecting Athens' efforts to gain support in the dispute with Turkey and secure oil supplies. Within the last ten years, such security objectives of Greek foreign policy have moved to the background and economic priorities have come to the fore. This has made relations with the Gulf States a crucial economic and diplomatic goal that has not been undermined by its ties to Iran and Israel. While the country's commercial relations with the GCC are regulated through the EU framework, it is through bilateral relations that Greece seeks to build its ties to the Gulf. Until now, the high expectations cultivated on the Greek side have not been fulfilled. Greece's relations with the GCC countries have remained anemic and investment limited. While a possible Grexit may have initially dampened investors' interest, the main obstacle continues to be one of domestic nature, reflecting the fragmentation and lack of coordination within Greek institutions themselves.

\footnotetext{
\# Professor, Department of Political Science and International Relations, University of the Peloponnese, Greece

${ }^{*}$ Global Distinguished Professor, Department of Environmental Studies, New York University, NYU Abu Dhabi
} 



\section{Looking for an Oasis of Support: Greece and the Gulf states}

\section{Introduction}

A recent review of European Union relations with the Middle East and North Africa (MENA) scholarship noted that there is 'a paucity of studies dealing with EU-GCC [Gulf Cooperation Council] relations' (Cavatorta \& Rivetti 2014). Indeed, this academic neglect has perhaps taken its cue from the relative inertia of EU officials in strengthening institutional relations with the GCC. A European Parliament Report (2010: 2) noted that 'the Gulf region (...) has long been neglected by EU policymakers, who do not manifest a strong political will towards it'. Also, two researchers concluded in 2014 that 'there is still no concerted EU policy in the Gulf beyond the thriving bilateral activities of some EU member states' (Demmelhuber \& Kaunert 2014).

While this picture seems telling, it is now not entirely accurate. Attention of European policy-makers and scholars has shifted in the direction of the Gulf as a result of the Arab Spring and the spread of the Iraqi conflict into Syria. The most recent mass exodus of Syrian and other migrants to Europe has increasingly transformed the wider MENA region into a source of instability and a growing security threat, resulting from failed states and the violent rise of ISIS (after the Paris bombings, increasingly referred to as DAESH [Stone 2015]). The crucial role of the countries of the Gulf in the fight against Islamic fundamentalism is therefore another 
factor of growing scholarly interest. Numerous articles, reports and books have been published within the last two years on the EU-GCC relationship with a prevailing security slant. European diplomatic activity increased as well, though it still has not secured concrete multilateral agreements. However, the increased academic research output continues to be confined either to security and secondarily economic aspects of the Gulf's relations with the West or to the foreign policies of a few powerful European countries that have strong and longestablished contacts, agreements and relationships with the region, especially with the UK, France and Germany (Legrenzi 2015; Ulrichsen 2015; Bicchi; Challand \& Heydemann 2015).

While the EU-GCC relationship remains the larger European framework for working with the countries in the Gulf, it is through bilateral negotiations that smaller EU member states can hope to build concrete, cooperative and productive ties in the GCC space. Until now, there has been extremely limited research on the foreign policies of smaller European countries towards the region, and on the ways that these interact with EU policies.

This paper aims to partly cover this gap by studying Greece's relations with the GCC area. It attempts to define and analyze the actors and the factors that shape the Greek-Gulf relationship and to understand how a small European state in the middle of a serious and deep economic crisis tries to attract the attention of distant, but economically powerful actors within the parameters of the wider European framework.

The paper proceeds in the following way: the first part examines in brief the international politics of the countries of the Gulf, emphasizing on 
current issues; the second part analyses EU-GCC agreements that regulate Greece's trade relations with the region and presents the main challenges that Brussels confronts; the third part presents Greece's bilateral relations with the Middle East and North African (MENA) region, starting from a historical perspective but focusing on more recent developments. The fourth and final part tries to reach some more general conclusions that may be of use in the study of similar cases.

\section{Strategic Challenges in the Gulf}

The GCC was formed in 1981. It has been argued that the main impetus for its formation at that time was the growing security concern that followed the Iranian revolution of 1979 and the start of the Iran-Iraq war of 1980 (Pradhan 2011: 265). There was a legitimate worry that postrevolutionary Iran would spread Shia radicalism to the Gulf countries which was additionally fueled by GCC perceptions of Iran as a state seeking to play a growing regional role based on its ideology of civilizational supremacy.

Iranian occupation of three disputed islands in the Gulf claimed by the UAE has further contributed to GCC views of Iran as a hegemonic actor, solidifying concerns that Tehran may attempt to fully control the Strait of Hormuz (Pradhan 2011: 267). Iran's persistence in launching a nuclear program has further aggravated the lack of trust, leading GCC countries to embark on civilian nuclear programs of their own. Moreover, GCC leaders increased military cooperation and political coordination.

The Arab Spring raised new warning signals for the Gulf putting Iran's behavior and capabilities under the microscope, especially following the 
uprisings and events in Egypt and Bahrain, in the Eastern Province of Saudi Arabia, in Yemen, and Syria. By 2011 an analyst concluded that 'the traditional Arab perception of Iran as a dominating and expansionist power [...] colors the thinking in the GCC countries' (Pradhan 2011: 274).

Since then, as the Sunni Arabs have become increasingly marginalized in the new Iraq, and as Iran has increased its influence throughout the region - especially in Iraq, Syria and Yemen - these perceptions remain stronger than ever. Today, the deployment of military forces and the provision of arms and money to Iraq and Yemen by both GCC countries and Iran indicate that suspicions are running high and relations remain tense (Economist 2015).

To fan the fire of insecurities and military build-up, questions about US 'disengagement' from the region have been worrisome to the GCC states. Following decades of active intervention in the area, the United States has been attempting to withdraw from the conflicts in Iraq and Afghanistan, and strategically pivot toward Asia where the rivalry with China is growing. Coupled with increased energy independence as a result of hydraulic fracturing, the United States is clearly signaling that it is time for its Gulf Allies to take-on new responsibilities (Shayiji 2014). In response to these developments, the GCC summit in Doha in 2014 agreed to 'a plan to establish a joint military command and joint naval force to be based in Bahrain, and supported by an Abu Dhabi-based Gulf Academy for Strategic and Security Studies' (Katzman 2015).

While the security relationship with the GCC countries remains of pivotal importance, there are noticeable differences between the Gulf States on a number of policy issues. Of particular concern for Gulf States is the 
rapidity of the rapprochement and normalization of US relations with Iran. The local monarchies hold different views from the Obama Administration on several issues but, most important is the American rapprochement with Iran: they worry that the recent nuclear deal signals 'American acceptance of Iran's hegemonic regional ambitions' (Al Shayiji 2014: 61). There were tensions over the nature of the Arab Spring. Its contagion made GCC leaders view it as a threat, while US inhibitions turned into support for democracy and freedom, once a number of regimes were toppled as a result of the upheaval. Moreover, disagreements loomed over policies vis-à-vis Syria, Iraq and Bahrain and have made the US-Gulf relationship even more complicated. It is the agreement of major powers with Iran on the nuclear question, however, and the rapid change of the world community's relationship with Tehran that has increased concerns about the importance of the Gulf's strategic significance for Washington and has led to questions about whether this rapid change of stance will prove a wise strategy in the long run for all parties involved.

Disagreements on alliances and foreign policy are also prominent in the GCC itself. Qatar, for instance, maintains close relations with Iran and has actively supported the Muslim Brotherhood in Egypt and elsewhere (Guzansky 2015: 114-5; Colombo 2012: 116-8). At the same time, Saudi Arabia declared the Muslim Brotherhood, a 'terrorist organization'. The UAE has also taken a more assertive stand toward regional Islamic movements, particularly when they are linked to the Muslim Brotherhood. On this position, they are aligned with Saudi Arabia and Bahrain. This specific foreign policy difference with Qatar led the UAE, Saudi Arabia and Bahrain to recall their Ambassadors from Qatar in 
March 2014. The rift was repaired in November of that same year (Katzman 2015), when they all agreed to further coordinate their foreign policies in order to avoid working against each other's interests. The UAE would also prefer to separate the issue of the disputed islands from economic considerations: after all, the Emirates are Iran's largest trading partner and Dubai is host to around 400,000 Iranian nationals (Guzansky 2015: 115).

Oman, with its extensive commercial ties with Iran and its relatively modest military capabilities, continually emphasizes its traditionally independent foreign policy although it remains an active broker in heated disputes. The Sultanate, has decided not to join the tighter Gulf Union proposed by the Saudis. Thus, as Guzansky has argued, 'the competition between Iran and Saudi Arabia set[s] the Gulf's security agenda, with the smaller Gulf monarchies maneuvering between them' (2015: 119).

While there are differences, the GCC is not in fact as split in its foreign policy agenda as some analysts argue. Most of the Gulf monarchies would like to curb Iran's hegemonic ambitions and limit its exploitation of the Sunni-Shiite feuds, because their own ethnic and religious composition could leave them exposed to outside interference. Bahrain, for example, with its depleted energy resources and its delicate sectarian composition (a Sunni minority ruling over a Shiite majority) has become a strong supporter of closer cooperation among GCC countries (Guzansky 2015: 116). And, several disagreements have been solved with the help of Kuwait's emir who 'has been active in fence-mending mediation' (Al Shayiji 2014: 68). Moreover, though in the beginning 
Saudi Arabia and Qatar had supported different parties and factions related to the Arab Spring, gradually their policies converged, leading to a 'division of labor', a division based on an external/domestic dichotomy: 'counter-revolutionary inside the Gulf and pro-revolutionary outside of it' (Colombo 2012: 119). Riyadh took the lead during the Yemeni and Bahraini uprisings, leaving Qatar to play the leading role in the Syrian revolution. Later Saudi Arabia supplanted Qatar as the leading supporter of the Syrian rebels. This convergence of Qatari and Saudi foreign policies largely reflected the change of leadership in Qatar (Economist 2013).

As the situation in the wider MENA region remains explosive, the United States has had to make significant efforts to strengthen the relationship with the GCC, creating a US-GCC Strategic Cooperation Forum and discussing with all six countries as a group, treating the GCC, at least at the security level, as one bloc (Al Shayiji 2014: 68). Other actors, however, have been given space to operate with the Gulf, while the US remains present but less engaged than in the past. These developments offer new opportunities for the European Union and its member states. The Europeans have also been encouraged by Washington to undertake more responsibilities (especially at the security level) in the region as part of 'burden-sharing'. As early as 1990, Henry Kissinger had noted that 'over a period of ten years, many of the security responsibilities that the United States is now shouldering in the Gulf ought to be carried out by the Europeans who receive a larger share of oil from the region' (US Senate 1990). Nevertheless, the EU, cognizant of the fact that relations at the institutional level have remained static, is more inclined to 
abandon its multilateral approach and deal with the Gulf monarchies individually.

\section{The EU and the Gulf}

EU-Gulf relations are based on the 1988 Cooperation Agreement that went into effect in 1990. The GCC's establishment of a customs union in 2003 gave a new impetus to negotiations with the EU, and there was hope that the first ever region-to-region Free Trade Agreement (FTA) would be signed (Antkiewisz \& Momani 2009: 218). However, in December 2008, the negotiations were suspended, signaling significant disagreements. There was renewed hope of success for regional cooperation when, in 2010, the Joint Action Program (JAP) was approved by the EU-GCC Joint Ministerial Council meeting in Luxembourg. It contained fourteen priority areas with suggestions for cooperative initiatives (European External Action Service 2010). As a result of this program, several projects were initiated creating 'a variety of networks whereby individuals and institutions from the GCC states and the EU c[a]me into regular contact to exchange information and expertise' (Koch 2013: 10). However, in 2013, the parties failed to produce a new Joint Action Program (JAP). In 2015, the $24^{\text {th }}$ GCC-EU Joint Ministerial Meeting was held in Qatar. The final communiqué noted vaguely the 'determination to address together common political, social, economic, and security challenges' ${ }^{1}$

${ }^{1}$ http://eeas.europa.eu/statements-eeas/2015/150524_01_en.htm 
It is abundantly clear that multilateral cooperation between the European Union and the GCC has stalled. The impasse is unfortunate for both sides. While both the EU and the GCC could be considered as leading examples of regional cooperation and integration, there are obstacles and weaknesses that hinder a more productive collaboration, even though a strategic dialogue between the parties is warranted (Colombo 2015).

The EU is the first trade partner of the GCC, accounting for $13.8 \%$ of its total trade in 2014 (followed by China, Japan and India with around 11\% each). The GCC is the EU's fifth largest export market. EU-GCC total trade increased spectacularly in recent years from $€ 100.6$ billion in 2010 to $€ 148$ billion in 2014. About $3 / 4$ of EU imports from the region are fuel and mining products, while its exports are manufactured products (mainly machinery, transport, equipment, and chemicals). The value of EU exports of goods to GCC is almost double the value of its imports. As far as the trade in services is concerned, the EU also maintains a surplus (€24.3 billion in exports compared with $€ 12.4$ billion of imports) (European Union 2015).

Nonetheless, the EU's share of the GCC trade is falling. In the words of an analyst: 'Six or seven years ago the EU accounted for about $31 \%$ of Saudi's imports, but now that is down to $25 \%$, while China has doubled its share during the same period' (EUI 2014: 18). The same is true of investment. Traditionally GCC countries have invested heavily in the EU (and the United States). However, their investment is mainly of the portfolio type (bonds, shares etc.) and, as a result of the recent economic crisis in Europe, GCC countries have increasingly been 
directing their investments to Asia (Toksoz 2010: 205).

The failure to conclude a Free Trade Agreement has been attributed to several factors. An important issue was EU repeated attempts to include political clauses (Demmelhuber \& Kaunert 2014: 579). The particular push came mostly from the European Parliament that requested a series of political reforms in order to endorse such an agreement (Colombo 2015). On the part of the EU, moreover, the low level of Europeanization of EU policies toward the GCC played a negative role in negotiations especially since, as previously mentioned, member-states' bilateral ties still dominated the discussion. Another significant aspect that hindered an agreement was a condition posed by the EU in order 'stabilize carbon dioxide emissions and improve energy efficiency'. To achieve these aims, 'the EC proposed a new energy and carbon dioxide tax aimed at lowering imports' (Colombo 2015). This would adversely impact the GCC countries that are fossil fuel exporters.

Political disagreements aside, there are major areas of dispute between the EU and the GCC that impeded progress on the FTA such as tariffs, export subsidies, and public procurement. A study funded by the Commission concluded that it would be the GCC - not the EU - that stands to gain the most from a FTA (PWC 2004: 105). However, rather strangely, EU member-states 'have not contested the EU-GCC FTA' (Antkiewicz \& Momani 2009: 222). Two sectors, specifically, dominated negotiations: petrochemicals and aluminum. Within the last decades, the GCC countries moved away from relying on basic petroleum exports and moved into the production of high value-added petrochemicals. Thus, the GCC asked for a reduction of the relevant EU trade barriers 
(PWC 2004: 164).

Gradually, the main issue in the negotiations became the GCC export subsidies to its petrochemical industry. For many years the EU's petrochemical lobby forcefully fought against trade liberalization arguing that the double pricing policy of raw materials by GCC countries constituted an indirect subsidy that would result in dumped imports entering the EU. The European Council of Chemical Manufacturers' Federation exerted significant pressure on the Commission to charge GCC countries (especially Saudi Arabia) with anti-dumping measures (Antkiewicz \& Momani 2009: 227). However, the Saudis managed to convince the WTO that export prices reflected added costs. This has put an end to EU petrochemical industry's allegations (European Parliament 2010: 11).

The second issue of trade disagreements was related to aluminum. The GCC had become a significant producer of aluminum products (almost 10 per cent of global output) while the EU imposed 6 per cent duty on aluminum imports (Antkiewicz \& Momani 2009: 224). Any liberalization of trade was expected to have adverse effects on the EU aluminum's industry.

Though some progress was made within the last years, it seems that trade continues to dominate the talks. As aptly put by an EU official ten years ago, 'The EU position is that we can offer some compromise and give some possibilities, but we cannot allow a completely free hand, otherwise it is not a real FTA' (EUI 2004: 19). Negotiations seem to have also stalled because of GCC countries' 'lack of transparency in public procurement procedures and barriers to entry for foreign investors in 
the services sector' (European Parliament 2010: 11).

A third and important factor for the failure to conclude a FTA was the disagreements among GCC members themselves. This is partly related to the different benefits that a FTA would bring to them (with Saudi Arabian petrochemical industry - especially SABIC - and the Bahrain aluminum industry benefitting the most), but it also reflected the difficulties of GCC countries to act unanimously. EU officials noted that GCC monarchies with domestic social contracts are antithetical to the concept of giving supranational authority to the GCC secretariat and, as a result, it is 'structurally difficult to come to an agreement' (quoted by Antkiewicz and Momani [2009: 223]).

In many respects, the GCC, with its lower degree of institutionalization, 'had very little experience in collective diplomacy and interregional dialogue and their negotiation team did not have a proper mandate' (Baabood 2003: 274).

A European Parliament report (2010:20) suggested that, 'given the institutional weaknesses of the GCC Secretariat and the previous episodes of regional divisions', the EU 'should adopt a hybrid approach, consisting in maintaining some relations on a multilateral basis while at the same time starting a more substantive approach to the individual countries'. In a sense, this was a belated adoption of US economic policy in the region that generally preferred signing bilateral FTAs with GCC members (Antkiewicz and Momani 2009: 231).

There continues to be no specific time-horizon for finalizing the FTA although events such as the $2013 \mathrm{EU}$ decision to end the system of 
Generalized System of Preferences for the GCC starting from January 2014, which led to the taxation of GCC petrochemical exports to the Union may 'pressure the GCC to conclude the FTA' (Konstandinova 2014: 10).

\section{Greece and the GCC}

As the EU and GCC seek ways to restart their inter-regional relationship, member states of the European Union cultivate their own ties to the region. While it is the United Kingdom, France and increasingly Germany who have longstanding ties in energy, security and trade, smaller members like Greece have been looking for ways to strengthen their relations, especially in the economic sector.

Greece has traditionally maintained strong ties with the Middle East. It was the only European state, for example, to vote against the partition of Palestine in the UN General Assembly in 1947 (Tsakaloyannis 1983: 128), and since then it has consistently backed the Palestinian cause. Even the leaders of the pro-American military dictatorship (1967-1974) had refused to grant the US over-flight or ground facilities to supply Israel with arms during the 1973 war, while allowing the Soviet planes to pass through the Greek airspace for the airlift of military supplies to Egypt (Tsakaloyannis 1983: 128). As a result, Greece was excluded from the Arab oil boycott.

In the 1980s, Greece developed even closer relations with the Arab world. This largely reflected a policy aimed at gaining support in the 
dispute with Turkey. Andreas Papandreou's October 1981 decision to raise the status of the Athens Information Office of the PLO to the same diplomatic level as Israel's representation in Greece (Keesing's Contemporary Archives 1982: 31264) was a clear response to Turkey's 1978 decision to accord a similar diplomatic recognition to Arafat's representatives in Ankara (Mackenzie 1984: 19). The PASOK government's rapprochement with 'radical' Arab regimes (Syria and Iraq) aimed, in the words of Greek Foreign Minister Papoulias, at 'detaching them from the influence of Turkey' (Oikonomikos 1987: 8). Furthermore, the diplomatic recognition of the PLO was based 'on the similarities between the Palestinian and the Cyprus tragedy' (Huliaras 1990: 164).

Yet there were also economic factors behind the Greek-Arab relationship. Since the 1970 s some Greek companies had achieved a prominent role in the Arab world where they were executing significant construction projects. Furthermore, the Arab markets were important for the export of Greece's agricultural products. The Arab world continued to be the second-largest export market for Greece (after the EC) throughout the 1980s and the first half of the 1990s.

In the first half of the 1980s, however, the Greek extreme proPalestinian stance complicated relations with moderate Arab regimes (especially in the Gulf) plus Syria and led Athens to gradually adopt a 'lower profile' in the region. In 1988 a Greek diplomat said that 'even the PLO is thinking of recognizing Israel. Why not we?' (quoted in Huliaras 1990: 173). Finally, in 1990 the newly elected New Democracy government granted Israel de jure recognition (Abadi 2000). 
While the Greco-Turkish relationship and the division of Cyprus remain high on the Greek foreign policy agenda these issues have also been Europeanized. The entrance of Cyprus in the EU during the wave of enlargement that officially ended Cold War divisions on the Continent allowed Greece some respite because Cyprus was now a member of the European family.

A constraint to the development of Greece's relations with GCC countries was Athens' close relationship with Tehran. The fact that Iran's relations with Turkey were strained gave the incentives to Greek foreign policy-makers to seek a political rapprochement with Tehran. In 1997 Iran, Armenia and Greece signed a Treaty of Friendship and Cooperation that included a clause on military cooperation. The Greek Defense Minister noted that his country aimed at developing a military partnership with Syria, Iran, Iraq, Armenia, Bulgaria and Russia, 'that is with all countries that have problems with Turkey' (quoted in Mirzoyan 2010: 123). Greece's NATO partners reacted negatively (Stratfor 1999) and Armenia finally decided not to join the military bloc (Mirzoyan 2010: 123). Athens had also second thoughts on the real potential of such a military rapprochement, and defence cooperation was largely abandoned. However, a trilateral cooperation was established, with officials from Armenia, Iran and Greece meeting regularly to discuss common projects on energy, transport and investment. Though not much was achieved, Iran gradually became an important provider of Greece's energy needs, offering extremely favorable credit terms that allowed Athens to buy Iranian oil on 60 days' credit without the need for bank guarantees (Patterson 2013: 134). In the 2006-11 period, Iran ranked first amongst Greece's oil suppliers (Brakoulias et al 2015). In 
2011, as major oil companies and banks refused to provide oil credit to a bankrupt Greece or asked for high risk premiums because of the possibility of Grexit, Tehran agreed to provide a credit line. Thus, Greek oil imports from Iran exceeded $50 \%$ of the country's needs (RT News 2012). However, the 2012 decision of the EU to impose a ban on the import of Iranian oil was a major blow for the relationship. Greece, which was the EU country that was expected to lose more from the embargo, was pressurized by Washington to accept the sanctions (Patterson 2013: 134). In the end, Greece as well as Italy and Spain were partly successful in persuading their EU partners to grant them a longer transition period in order to find alternative supplies. Athens was able to replace Iranian oil with imports from Russia, Saudi Arabia and Iraq (Giumelli and Ivan 2013: 18).

In parallel, Greece tried to find ways to attract Iranian funds. In October 2015, an Athens newspaper revealed that the Greek General Secretary for International Economic Relations visited Tehran to persuade the Iranians to buy Greek government bonds (Ta Nea 2015). It can be argued that Greece's relationship with Iran did not act as a serious constraint for the development of ties with the GCC (Interview 1); indeed, it may have acted more as a disincentive, since Iran provided much of the country's oil needs.

Another development that initially seemed to have the potential to endanger Athens' relations with the Arab Word was Greece's rapprochement with Israel. Turkey's rift with Israel in 2009 hastened and intensified cooperation between Israel, Greece and Cyprus (Tziampiris 2015). However, the relations with Israel that soon expanded into 
several sectors (ranging from energy to military cooperation) did not seem to have a direct impact on relations with the Arab world and the GCC in particular.2 This is partly related to Tel Aviv's relations with the GCC: though Israel does not have official diplomatic relations with the countries of the Gulf, the common threat, Iran, has led to the maintenance of active, albeit tacit, avenues of communication (Guzansky 2015a). As a result, Greece's growing ties with Israel have not acted as a constraint for cooperation with the GCC.

\section{From security to economics}

Greece's adoption of the euro in 2001 coincided with high growth rates and a campaign to attract foreign investment. A shift to 'economic diplomacy' soon became visible. A clear indication of the new priority was that the government of Kostas Simitis decided to incorporate commercial attachés (employees of the Ministry of National Economy) into the Ministry of Foreign Affairs. While this was a sound decision, it remained problematic in its execution. Unfortunately, as we will discuss later on, the Ministry of Economy, Infrastructure, Maritime Affairs and Tourism continued to maintain the responsibility for foreign direct investment, creating a bureaucratic division that has complicated efforts to broker important economic deals. Therefore, despite efforts to facilitate decision-making and improve coordination, Greek foreign

\footnotetext{
${ }^{2}$ Interview with the Director of the Institute of International Economic Relations, Dr Charalambos Tsardanidis, Athens, 14 October 2015.
} 
policy remained largely separate from foreign economic policy throughout the last fifteen years.

Because of its traditionally good relations with the Arab world, the dominant perception was that relations with Gulf states would automatically and naturally produce fruit that would benefit Greece in its time of need. The situation, however, was far different. While Greece has maintained a pro-Arab stance throughout the last decades, it should be underlined that its political and economic ties were largely limited to the Mediterranean region. It would, therefore, be a mistake to conflate these countries (Egypt, Syria, Jordan, Algeria, Libya, to name a few) with the Gulf where relations were not as pronounced. Secondly, the past 40 years have brought about a dramatic transformation of the Gulf countries as they have taken over the management of their own energy resources and have benefited immensely from a prolonged period of high oil prices, rendering them global economic powerhouses and leading them to quite different directions from the rest of the Arab world.

Today, these relatively sparsely populated lands have attracted millions of people, mostly from Europe, Asia and Africa, that are contributing to the diversification of their oil economies with the building of new ultra modern infrastructure, the creation of world class universities and research centres, and the development of tourism. The Gulf countries either as states or at an individual level are major investors all over the world, but they are also seeking to work with reliable partners, preferably large and established companies, to help them build the physical environment and to buy financial and other prized assets in all 
corners of the globe. They are also attracting the world's brightest to lead in education and innovation in industry, energy, design, health etc. Furthermore, in response to the new security environment and the growing instability in the wider MENA area, the Gulf States are heavily investing in defence and security. Their view of security is not limited to traditional arms purchases and defence alliances. Having factored in the threats of climate change and their water resource poverty, they are exploring ways to ensure food security, as well investing heavily in agricultural land all across the planet. These are the parameters that interest them as they seek investment opportunities and a diversification of their economic portfolios that no longer rely exclusively on the sale of fossil fuels.

As a member of the EU, Greece's multilateral economic relations inevitably comply with the more general EU-GCC framework. Interestingly enough, a possible FTA agreement may not prove beneficial to Greek economic interests. Under an FTA agreement, there are two economic sectors of vital importance for Greek exports that are particularly vulnerable: petrochemicals and aluminum. The next paragraphs examine each of them in turn.

Almost all the crude oil used in Greece, accounting for some $45 \%$ of the country's energy needs, is imported. Most of it comes from Middle Eastern countries, as well as the Russian Federation (IEA 2014: 220-1). The Greek refining industry is dominated by two companies: Hellenic Petroleum and Motor Oil Hellas. The Greek state currently owns 35.5\% of the largest one, Hellenic Petroleum, which is, however, in the process of privatization. The companies' four refineries produce around 575,000 
barrels a day, providing more than 40,000 jobs, mostly in the wholesale and retail sector. Greece is a net exporter of refined products to a number of countries (mainly Turkey). It is a strange situation: nearly $38 \%$ of Greece's export revenue in 2012 was generated from refined products, while crude oil accounted for $24 \%$ of the country's imports (Ausick 2015). With decreasing domestic demand (due to the economic crisis), Greek domestic refinery production exports have increased in recent years. An FTA agreement with the GCC could pose a serious challenge for the sector.

Table 1: Greek Exports to Saudi Arabia and U.A.E. (2004-14)

Million US \$

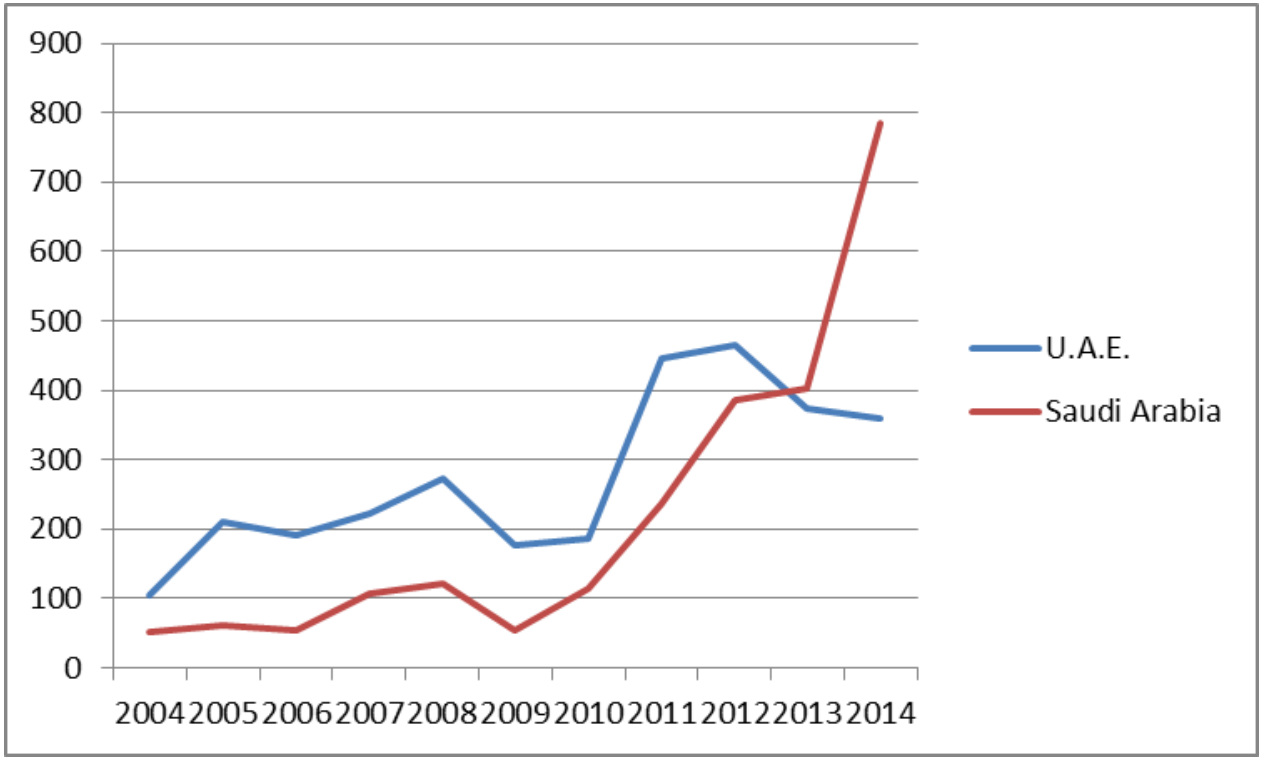

Source: ELSTAT, Greek National Statistics, Calculations by the authors.

The second sector is aluminum. Greece has some of the largest bauxite deposits in Europe and has become one of the few European countries that has a vertically-integrated aluminum industry where the different processing stages (from bauxite to internationally certified end use products) are all located in close proximity (especially Boeotia and 
Central Greece). The industry comprises about 8,000 large and small companies that employ around 30,000 people. Aluminum is the second most important sector for Greek exports (accounting for 1.3 billion Euros or $4.7 \%$ of the total)3. The largest company is Aluminum SA, part of the Mytilineos Holding company, that has an annual production capacity over 170,000 tons of aluminum and 810,000 tons of alumina. It employs 1,100 workers. High electricity prices have been an area of persistent renegotiation and litigation battles with the Greek Public Power Corporation. If an FTA with the GCC were to become a reality this would further impact on the competitiveness of the Greek aluminum industry.

However, and despite the possibility of particularly high costs from the signing of a trade agreement, there is no evidence whatsoever that Greece has contested the EU-GCC FTA at the initial discussion in the Council or at any stage of the negotiations during the past 20 years. The authors could not find any reference in official documents (ranging from Commercial Attachés' Reports to communiqués of bilateral or multilateral meetings) on the issue.

In general, the Gulf has not been much of a factor in Greek external trade. In 2013, Greek imports from the GCC accounted for $4.6 \%$ of the total and Greek exports to the GCC for $5.1 \%$ of the total. Greece has a trade deficit with all GCC countries, with the exception of the UAE. Despite a recent rise, Greek exports are very low in terms of value. For example, in the case of Saudi Arabia they usually cover $1 / 2$ to $1 / 5$ of

\footnotetext{
${ }^{3}$ Aluminium Association of Greece (http://www.aluminium.org.gr/index.php?language=en)
} 
imports and are limited to very few products, mainly refined oil and crystalline limestone (marble). In the case of $U A E$, next to petroleum products, Greece exports furs and leather.

With Saudi Arabia, political relations are anemic at best. Official visits have decreased over the last few years. Moreover, the Joint Ministerial Committee that is of crucial importance for promoting relations has not met since 1999 (Interview 2). But some Saudi investors have a strong presence in Greece. For example, Olayan, Saudi Arabia's biggest investment group, has a long-standing presence in Greece, being one of the biggest stakeholders in Greek bottler Coca-Cola HBC and the Chipita food company. The Saudis have also participated in the share capital of Athens-listed company Flexopack. In late 2014, it was reported in the press that Olayan is entering Costa Navarino resort in southwestern Peloponnese as the fourth shareholder with an equal stake to those of the Konstantakopoulos family (Dokas 2014). Olayan is chaired by Khaled Olayan who (with his three sisters) is estimated to control a fortune of \$12 billion, making him one of the world's richest people. Khaled's father is Greek. However, these moves are not linked to official contacts. In contrast, there were some official initiatives that failed to reach the stage of implementation. A proposal of the local Greek embassy to offer members of the Saudi Royal Family and government officials visa-free entry to Greece was not endorsed by the Greek Foreign Minister (Interview 5). Political and economic relations with Yemen and Oman are insignificant. Greece's relations with the GCC countries are centered on the UAE and Qatar. 
Opportunities in tourism, education and health are increasingly attracting Greek human capital to these two states. While there is still much untapped potential for Greek enterprises as well, the past few years have seen investment activity in Greece from both UAE and Qatar. The crisis of the past years, however, while offering interesting business opportunities for foreign investors has also been characterized by Greek government inconsistency. Some projects have moved forward, but others have ended up in failure, tarnishing the reputation of Greece as a reliable place to do business.

In May 2014, the UAE announced the launch of a \$9.75bn investment project in Greece. The project is a joint venture of the Abu Dhabi-based Al Maabar International Investment with the Greek shipowner and real estate developer Latsis Group (Lamda Development) and the Chinese company Fosun. It aims at the redevelopment of the old Athens airport (Hellenikon), a site of 6.2 million square meters next to the sea. The project is expected to generate around 50,000 jobs (Sambidge 2014). However, the SYRIZA-led government that was elected in January 2015 seemed to have second thoughts. The Minister of Productive Reconstruction, Environment and Energy, Panayiotis Lafazanis, told the Greek Parliament in February 2015:

The acquisition of Hellenikon was scandalous and the development plans are extremely destructive to the environment. We will review this scandalous purchase with the aim of cancelling it (quoted in Glass 2015).

Nevertheless, it seems that other members of the Greek government did not share this position. At the same time, there is much continuity in Greek foreign policy in the region, despite the change of government. In 
March 2015 the new Greek Foreign Minister Nikos Kotzias visited the UAE and met with the Foreign Minister, Shaikh Abdullah Bin Zayed Al Nahyan, to discuss 'ways to bolster relations' (Gulf News 2015). One year before (during the previous New Democracy-PASOK government), the UAE Foreign Minister Shaikh Abdullah Bin Zayed Al Nahyan officially visited Athens where he co-chaired the second meeting of the UAEGreece Joint Ministerial Committee along with Greek Deputy Prime Minister and Foreign Minister, Evangelos Venizelos, in the presence of Dr. Sultan bin Ahmed Al Jaber, Minister of State (Gulf News 2015).

This kind of diplomatic activity, with Greek officials visiting Abu Dhabi and Doha, is typical of the crisis years. In 2010, the Emir of Qatar, Sheikh Hamad bin Khalifa Al Thani, met the Greek Prime Minister, George Papandreou, in New York at the sidelines of the 65th UN General Assembly session. The two leaders attended 'a visual presentation about the Qatari investment opportunities in Greece, and witnessed the signing of a memorandum of understanding to set up a joint committee between the Qatar Investment Authority and the Greek government regarding the Qatari investments in Greece4. In 2011, it was announced that Qatar Holding agreed to provide the Canadian-owned European Goldfields with $\$ 750 \mathrm{~m}$ to fund the development of two gold mines in Khalkidiki, northern Greece. Thus, the Qatari sovereign wealth fund became the largest single shareholder in Greece (Rowley 2011). However, the investment has divided local residents in Khalkidiki, with some fearing environmental damage and a drop in tourism and others

\footnotetext{
${ }^{4}$ Embassy of Qatar in Athens (http://www.qatarembassy.gr/index.php?new_language=2).
} 
welcoming the nearly 2000 jobs the investor provided at a time of economic crisis and high unemployment.

Apart from Qatar, there are also investments in Greece from the UAE. In 2014, two Greek government members - the Minister of Infrastructure, Transport and Networks and a Deputy Minister on Development and Competitiveness - visited the UAE. Talks included investment, tourism and energy cooperation. More recently, Greece has been strengthening its ties in the area of defence and specifically in the supply of defence materials. There have been a number of official visits to the Gulf and particularly the UAE by the Minister of Defense Panos Kammenos.5 Furthermore, the Abu Dhabi MAR holds shares in the Greek Marfin Investment Group (Greek Embassy 2014). The Greek Defence Systems company cooperates with UAE's IGG for the provision of ammunition and the Greek Restis Group signed a MoU with the UAE International Petroleum Investment Company on energy cooperation. Also, the staterun Abu Dhabi Investment Council has offered to buy the Astir Palace resort in Athens (Shahine 2014). Greek companies have also invested in the UAE. The Greek Commercial Attaché in the UAE remarked that 170 Greek companies are present in the Emirates, mostly in the construction, fur, and shipping sectors (Greek Embassy 2014). Among others, Vivartia, a member of the Marfin Group, signed an initial agreement with Exeed Industries for the production of dairy products, juices and tea in Abu Dhabi (Greek Embassy 2014). Reflecting the growing Greek

\footnotetext{
${ }^{5}$ Mohamed bin Zayed receives Greek defense minister, WAM Emirates News Agency, November 9, 2015, viewed on December 1, 2015, https://www.wam.ae/en/news/emirates/1395287787543.html
} 
entrepreneurial activity in the country, a Greek Business Council was created in Dubai.

Prolonged fears of a Grexit as well as the imposition of capital controls seem to have worried at least some GCC investors, although other policy inconsistencies and bureaucratic obstacles acted as stronger deterrents. Though the direct impact of a Grexit on the GCC economies was considered as 'minimal', mainly by affecting the euro's exchange rate against the US dollar, institutional investors and high net worth individuals seemed rather worried about the future value of their investments in Greece (Augustine 2015). Nevertheless, the Greek economic crisis also offered new opportunities. For example, Kuwait's Al Ahli Bank bought Piraeus Bank's unit in Egypt, paying \$150 million cash for a 98.5 percent stake in the business and giving Greece's Piraeus a much-needed liquidity boost (Reuters 2015).

Greek officials, however, seemed undeterred by the negative milieu. The Greek Alternate Minister of Tourism, Elena Kountoura, made an official visit to UAE in June 2015 trying to attract tourists and investment. In an interview she noted that Greece was a 'strong supporter' of the Schengen visa waiver for the Emirates, which was granted to the UAE in the summer of 2015 (Carroll 2015). Other Gulf countries have not secured such a waiver.

Exchanges continue unabated and perhaps some success can be achieved from the mere fact that investors in Greece can now acquire immediate citizenship by investing 2.5 million euros (assets which can be sold only after 3 years) or are granted EU permanent residency by putting a deposit worth 250,000 euros into a Greek bank account. If 
there is any hope, however, of building long-term healthy ties with countries in the Gulf, Greece needs to rethink its entire approach to investment. Thus far, all attempts to attract investment have been riddled by a lack of strategic planning, coordination and continuity, resulting in different business deals that rely almost exclusively on private relationships.

However, it should be underlined that GCC investors were until very recently almost non-existent in the country (UNCTAD 2012). The Greek economic crisis and the fears of Grexit proved insufficient to deter GCC investment decisions: new plans were announced and deals sealed. Nevertheless, GCC capital in Greece - as in the rest of the EU consists of mostly portfolio investments in deposits, bonds and equities (Fürtig 2010: 30).

Greek construction companies have won several bids in the Gulf, usually taking part in bids along with foreign companies undertaking major infrastructure projects. The Greek company Ellaktor, owned by the Bobolas family, is the leader of a consortium that includes the Indian multinational Larsen \& Toubro, the Turkish companies Yapi Merkezi and STFA, and Qataro Al Jaber Engineering; together they won a contract of 3,9 billion euros for the construction of Doha's 'Gold Line Underground' that forms part of the Qatar Integrated Rail Project and is by far the largest single construction package of the Doha Metro (Roussanoglou 2014). This is the largest contract ever signed by a Greek company abroad. J\&P construction, which has a strong presence in the Middle East, has also won several bids for the construction of roads in Qatar and other countries of the Gulf. 
Greek construction companies, however, work mainly as sub-contractors in the Gulf, having missed an important wave of opportunities to win bids in the Gulf during the period of high oil prices. At that time they were all heavily involved in the construction of facilities and infrastructure required for the 2004 Olympic games in Athens (Interview 2). The first decade of the 21st century saw a record construction push in the Gulf that is now significantly slowing down because of low oil prices. In addition, companies from India, China and elsewhere have already been in the region long enough to form the necessary ties and track record to continue to bid and build.

With direct flights in short supply since the breakdown of Olympic Airways, Greece's flag carrier, Qatar Airways, Emirates of Dubai and Etihad of Abu Dhabi, have become important carriers for linking Greece with the East. The location of the Gulf is crucial for eastbound flights to destinations such as Australia, home to the second-largest overseas Greek population. The passenger tally on the Emirates service, for example, reached 224.000 in the year through March 2015. Carrying seafarers for Greece's shipping industry has also played a role in these increased numbers (Yousef and Weiss 2015).

Greece has a long history of emigration, and the recent economic depression has led to a new exodus. From 2010 to 2013, about 218,000 Greeks emigrated, according to an estimate from the Greek statistics agency (Angelos 2015). Many are highly skilled with degrees in engineering and medicine. It is estimated that around 135,000 have post-secondary degrees. The GCC has witnessed an impressive rise in Greek migrants. Especially Dubai and Abu Dhabi and to a lesser extent 
Saudi Arabia and Qatar have become major recipients of Greek professionals, mainly working as engineers in the construction sector, the hospitality industry and in retail businesses. The majority of migrants are skilled laborers who have not brought their families with them, hoping to return to Greece soon. The fact that the construction sector is highly vulnerable to changes in oil prices means that the emergence of a permanent Greek diaspora in the region should not be considered as a secure prediction.

Greece's relations with GCC countries are characterized by longestablished friendships, networks of personal trust, and connections formed by kinship (usually marriage). A few dozen key figures have facilitated or impeded relations. Some of them can be found in higher echelons of the Greek political class, but most of them derive from the private commercial sector. Some were visible in public life and others hidden in agreements that remained secret. Indeed, several Greek Prime Ministers, including Papandreou and Samaras, approached the region by sending personal envoys. For example, in 2010, when Greece tried to settle a four-year dispute with Germany about an allegedly unseaworthy submarine, the Greek Prime Minister George Papandreou approved the sale of 75 per cent of the Scaramanga shipyard near Athens, owned by the German company ThyssenKrupp, to Abu Dhabi Mar. Nikos Papandreou, the prime minister's brother, who held no official position, was sent to Abu Dhabi to 'seal' the deal (Hope 2010). Officials of the Greek Foreign Ministry argued that the choice of bypassing the diplomatic service was made because of the 'urgency of the situation' (the German company had decided to sell the shipyard after the production of other submarines was canceled). After his trip to the Gulf, 
Nikos Papandreou told Athens newspapers that 'I would turn somersaults if I had to, in order to rescue Greece' (Hope 2010a). However, it was not the only instance where Nikos Papandreou was involved. The same year, he failed to persuade the Qataris to be involved in the Liquified Petroleum Gas project in Astakos, Greece.

General investment pledges by GCC countries to Greece have largely failed to materialize because of planning inconsistencies in Greece that have led to over-expectations and unfilled promises to investors. For example, though the then Emir of Qatar, Hamad bin Khalifa Al Thani, paid $€ 8.5 \mathrm{~m}$ for 6 lonian islets (Smith 2013), Qatar withdrew from the international tender for the redevelopment of Hellenikon Airport. Although Antonis Samaras, Greece's PM at the time, visited Doha in a desperate attempt to persuade Qataris to change their minds and to secure new concrete investment pledges (Reuters 2013), he failed.

\section{Conclusions}

While Greece has prided itself on having close historic bonds to the Arab world (Agnantopoulos 2007), this has proved far from enough for promoting collaboration with GCC states. In fact, the region had been neglected by Greek foreign policy-makers until very recently.

As a member of the EU, Greece's relations with the Gulf inevitably fall under the framework of any agreements that may be achieved at a multilateral level, even if a particular FTA agreement may not be in Greece's interests. With the important role of the petrochemical and aluminum industries for its exports, Greece has much to lose from the 
liberalization of trade with the GCC. Of course, free trade agreements concluded by the EU still require national ratification by each memberstate (Glencross 2009: 188). Moreover, the Lisbon Treaty has introduced a procedure whereby the European Parliament's consent is necessary for all international agreements the EU makes (Glencross 2009: 104). Thus, Greece (and other member states) can exert influence in various stages of the process. Still, while an EU-GCC FTA may not be concluded in the near future, there remain important questions concerning the impact of EU Common External Trade Policy on its poorer members that require further study.

Greece's belated diplomatic turn toward the Gulf is a result of two significant changes in the country's fortunes and focus. First, and foremost, it can be attributed to a clear reprioritization of diplomacy toward the fulfillment of the nation's economic agenda, aiming at attracting foreign investment and, to a lesser degree, promoting exports. Second, the economic crisis itself has made economic diplomacy a matter of paramount importance.

The systematic cultivation of two relationships reflects this emphasis on economic issues: Greece's rapprochement with China (Huliaras \& Petropoulos 2014) and the relationship with the Gulf States examined in this paper. In both cases, the ties developed within the last decade have almost a dominant, if not exclusive, economic dimension. In both, the role of private players (businessmen and companies) has been crucial. In both, there has been much continuity regardless of the governments in power; their objectives and methods have been nearly identical. Above all, in both the high expectations have remained largely unfulfilled. 
Despite some investment activity, mainly of the portfolio type, exports remain at low levels. Similarly, attempts to involve the Gulf States in the privatization program of public assets has yielded mixed results and future outcomes remain to be seen.

Undoubtedly, the prolonged threat of a Grexit and the imposition of capital controls have, in themselves, served as a strong deterrent to investment in Greece. It is important to note with regard to Greece-GCC relations that Greek ties to Iran and, more recently, to Israel have not constrained, impeded or complicated the rapprochement with the countries in the region. The main obstacle continues to be one of a domestic nature reflecting the fragmentation and lack of coordination within Greek institutions themselves.

Thus far, with regard to investment flows, Qatar and the UAE have dominated Greece's relationship with the Gulf. Foreign investments in Greece, mainly of the portfolio type, have come largely from these two countries. However, very little of this investment is related to government contacts. Official visits have been numerous in the post2009 period, but there is no evidence that, apart from a small number of instances, they have produced substantial results. The fragmentation of policy-making on the Greek side along with the persistent lack of coordination among ministries and government agencies dealing with foreign economic policy, have proven important constraints on the development of a more structured and possibly more successful policy.

In short, Greek official initiatives have looked spasmodic, lacking clear objectives and specific plans. In the words of a Greek diplomat, 'we received no directives from Athens and there was a lack of organization, 
planning and coordination throughout' (Interview 2). Greek prime ministers and ministers may have visited Abu Dhabi and Doha, helping to put Greece on the map, but have not yet produced conclusive results.

While foreign policy concerns such as the Cyprus problem, relations with Turkey, and disputes about the name of FYROM remain at the centre of Greece's diplomatic efforts, increasingly it is economic diplomacy that is taking precedence. In order for Greece to have any chance of success, be it in its overtures to the GCC or its own recent rapprochement to China (Huliaras \& Petropoulos 2014), it will clearly need to re-organize internally (institutionally first and foremost), to set clear rules and goals for attracting foreign investment, and to systematically explore export opportunities abroad. Without a clear plan and an institutional overhaul, outcomes will be haphazard, and economic relations will continue to be based on individual ties and single projects. 


\section{References}

Abadi, Jacob (2000) 'Constraints and Adjustments in Greece's Policy Toward Israel', Mediterranean Quarterly, Vol. 11 (4), Fall, pp. 40-70.

Agnantopoulos, Apostolos (2007) 'Greece and the Palestinian-Israeli Conflict: A Discursive Perspective', Mediterranean Politics, Vol. 12 (3), pp. 359-79.

Albawaba Business (2015) 'Giving up on the EU ? Greece, Cyprus look to GCC investors', 23 February http://www.albawaba.com/business/giving-eu-greececyprus-look-gcc-investors-660622.

Aluwaisheg, Andel Aziz (2015) 'EU, GCC and Syrian refugees', Arab News, 12 October http://www.arabnews.com/columns/news/816176.

Angelos, James (2015) 'Greece's Relentless Exodus', The New York Times, 28 July http://www.nytimes.com/2015/07/29/opinion/greeces-relentlessexodus.html?_r=0

Antkiewicz, Agata \& Bessma Momani (2009) 'Pursuing Geopolitical Stability through Interregional Trade: the EU's Motives for Negotiating with the Gulf Cooperation Council', European Integration, Vol. 31 (2), March, pp. 217-35.

Antoniou, Dora (2015) 'I mistiki syskepsi ton Maio gia to Plan B', I Kathimerini, 11 October [in Greek].

Augustine, Baba das (2015) 'Greek capital controls hit payments, business transactions with GCC', Gulf News, 29 June http://gulfnews.com/business/economy/greek-capital-controls-hit-paymentsbusiness-transactions-with-gcc-1.1542677

Ausick. Paul (2015) 'Greek Economy Relies on Refined Product Exports', 24/7 Wall St., 29 June http://247wallst.com/energy-economy/2015/06/29/greekeconomy-relies-on-refined-product-exports/

Baabood, Abdulla (2003) 'Dynamics and Determinants of the GCC States' Foreign Policy with Special Reference to the EU', Review of International Affairs, Vol. 3 (2), Winter, pp. 254-62.

Bicchi, Federica, Benoit Challand and Steven Heydemann, eds. (2015) The Struggle for Influence in the Middle East: The Arab Uprisings and Foreign Assistance, London: Routledge. 
Brakoulias, Chr., C. Levoyannis and A. Ghanoutas-Leventis (2015) 'Greeca and Iran: two old friends can change the geopolitics of energy in Europe', Energy Post, 8 May http://www.energypost.eu/greece-iran-two-old-friends-canchange-geopolitics-energy-europe/

Carroll, Dean (2015) 'Greece launches tourism charm offensive in UAE', Gulf Business, 11 July http://gulfbusiness.com/2015/07/greece-launches-tourismcharm-offensive-uae/\#.VhypoPntlBc

Cavatorta, Francesco \& Paola Rivetti (2014) 'EU-MENA Relations from the Barcelona Process to the Arab Uprisings: A New Research Agenda', Journal of European Integration, Vol. 36 (6), pp. 619-25.

Colombo, Silvia (2012) 'The GCC and the Arab Spring: A Tale of Double Standards', The International Spectator, Vol. 47 (4), December, pp. 110-26.

Colombo, Silvia (2015) The GCC, the EU and the Merits of Inter-Regionalism, Gulf Research Center, Gulf Papers, November 2014 http://mercury.ethz.ch/.../Unity_Paper_Silver_new_18-11-14_4181.pdf .

Davidson, Christopher (2007) 'The Emirates of Abu Dhabi and Dubai: Contrasting Roles in the International System', Asian Affairs, Vol. XXXVIII (1), March, pp. 33-48.

Demmelhuber, Thomas \& Christian Kaunert (2014) 'The EU and the Gulf monarchies: normative power Europe in search of a strategy for engagement', Cambridge Review of International Affairs, Vol. 27 (3), pp. 574-592.

Dokas, Anestis (2014) 'Saudi group Olayan to enter Costa Navarino', Kathimerini (English edition), $27 \quad$ November http://www.ekathimerini.com/165056/article/ekathimerini/business/saudigroup-olayan-to-enter-costa-navarino

Economist Intelligence Unit, GCC Trade and Investment Flows, London: EIU, 2014.

http://www.economistinsights.com/sites/default/files/GCC\%20Trade\%20and \%20investment\%20flows.pdf.

Economist, The (2013) 'Qatar's Foreign Policy: Change of trade', 15 July.

Economist, The (2015) 'Containing Iran: The Sunnis strike back', 28 March. 
Eissa, Noura Abdel Maksoud (2014) 'The Analysis of EU-GCC Potential Free Trade Area Agreement Through EU-GCC Actual Steps ( 1995-2012)', World Review of Political Economy, Vol. 5 (3), Fall, pp. 331-358.

European Union (2015) 'Trade in Goods with GCC' (http://trade.ec.europa.eu/doclib/docs/2006/september/tradoc_113482.pdf.

European Parliament (2010) Relations between EU \& Gulf Cooperation Council (GCC) Countries, Brussels: Directorate General for External Policies, Policy Department http://www.europarl.europa.eu/RegData/etudes/note/join/2010/433742/EXP O-AFET_NT(2010)433742_EN.pdf

European Union (2015) EU Trade with GCC http://trade.ec.europa.eu/doclib/docs/2006/september/tradoc_113482.pdf

Fathalla, Amira (2015) 'Why Syrians do not flee to Gulf States', BBC Monitoring, 2 September http://www.bbc.com/news/world-middle-east-34132308.

Fürtig, Henner (2004) 'GCC-EU Political Cooperation: Myth or Reality ?', British Journal of Middle Eastern Studies, Vol. 31 (1), May, pp. 25-39.

Giumelli, Francesco and Paul Ivan (2013) The Effectiveness of EU Sanctions, EPC Issue Paper No 76, November, Brussels: European Policy Center http://www.epc.eu/documents/uploads/pub_3928_epc_issue_paper_76__the_effectiveness_of_eu_sanctions.pdf.

Glass, David (2015) 'Greek government seeks to reassure Chinese premier Li', Seatrade Maritime News, 17 February http://www.seatrademaritime.com/news/asia/greek-government-seeks-to-reassure-chinesepremier-li.html.

Glencross, Andrew (2009) What makes the EU viable? European integration in the light of the antebellum US experience. Palgrave Macmillan.

Greek Embassy in UAE (2014) Etisia Ekthesi Dimeron Oikonomikon kai Emporikon Sheseon Elladas-HAE, Dubai: MFA [in Greek] http://www.agora.mfa.gr/frontoffice/portal.asp?cpage=NODE\&cnode=57\&fid $=44996 \#$

Gulf News (2015) ‘Abdullah meets Greek Foreign Minister', 25 March 
http://gulfnews.com/news/uae/government/abdullah-meets-greek-foreignminister-1.1478400

Guzansky, Yoel (2015) 'The Foreign-Policy Tools of Small Powers: Strategic Hedging in the Persian Gulf', Middle East Policy, Vol. XXII (1), Spring, pp. 11222.

Guzansky, Yoel (2015) 'Israel and the Arab Gulf States: From tacit cooperation to reconciliation ?', Israel Affairs, Vol. 21 (1), pp. 131-47.

Hope, Kerin (2010) 'Greek shift over German-built submarine keeps aid hopes afloat', Financial Times, 20 March

http://www.ft.com/intl/cms/s/0/a2f39540-33c0-11df-8b99-

00144feabdc0.html\#axzz3oHMUgarF

Hope, Kerin (2010) 'Greek premier seeks foreign investment', Financial Times, 21 May http://www.ft.com/intl/cms/s/0/4e202756-64fb-11df-b64800144feab49a.html\#axzz3oHMUgqrF

Hope, Kerin (2011) Canadian Company to run Greek gold mines, Financial Times, 19 December

Huliaras, Asteris (1991) The Foreign Policy of the Greek Socialists: Forces of Continuity and Change, Unpublished Ph. D. Thesis, University of Hull.

Huliaras, Asteris and Sotiris Petropoulos (2014) 'Shipowners, Ports and Diplomats: The Political Economy of Greece's Relations with China', AsiaEurope Journal, Vol. 12 (3), September, pp. 215-30.

Hürsoy, Sıret (2013) 'Turkey's Foreign Policy and Economic Interests in the Gulf', Turkish Studies, Vol. 14 (3), pp. 503-19.

International Energy Agency, Energy Supply Security 2014, Washington DC: IEA https://www.iea.org/media/freepublications/security/EnergySupplySecurity2 014_Greece.pdf

Kathimerini (English edition) (2013) 'PPC threatens to ditch top client Aluminium in price row', 8 November http://www.ekathimerini.com/155292/article/ekathimerini/business/ppcthreatens-to-ditch-top-client-aluminium-in-price-row

Kathimerini (English edition) (2015) 'SYRIZA MPs preparing vote for recognition of

Palestine', 21 May 
http://www.ekathimerini.com/197129/article/ekathimerini/news/syriza-mpspreparing-vote-for-recognition-of-palestine.

Katzman, Kenneth (2015) The United Arab Emirates (UAE): Issues for U.S. Policy, Congressional Research Service, 7-5700, RS21852, September 14. https://www.fas.org/sgp/crs/mideast/RS21852.pdf

Kerr, Simeon (2015) 'Gulf states under pressure to take Syrian migrants', Financial Times, 4 September http://www.ft.com/intl/cms/s/0/55f828a85216-11e5-8642-453585f2cfcd.html\#axzz3oHMUgqrF.

Koch, Christian (2013) Constructing a viable EU-GCC Relationship, Kuwait Programme on Development, Governance and Globalisation in the Gulf States, London: LSE http://eprints.Ise.ac.uk/55282/1/Constructing-a-viable-U-GCCrelationship.pdf.

Konstandinova, Valentine (2013) What is the Status of the EU-GCC Relationship ?, Gulf Research Center, GRC Research Papers http://eugcc.kcorp.net/common/publicationfile/29.pdf.

Larrabee, Stephen F. (2011) 'Turkey and the Gulf Cooperation Council', Turkish Studies, Vol. 12 (4), December, pp. 689-98.

Legrenzi, Matteo (2015) The GCC and the International Relations of the Gulf, London: I. B. Tauris.

Leigh, Michael (2014) 'Energy: A Geopolitical Game Changer ?', The International Spectator, Vol. 49 (2), pp. 1-10.

Mackenzie, Kenneth (1984) Turkey in Transition: The West's Neglected Ally, Institute for European Defence and Strategic Studies, European Security Studies, No 1, London.

Mirzoyan, Alla (2010) Armenia, the Regional Powers and the West: Between History and Geopolitics, London: Palgrave Macmillan.

Odinius, Daniel and Philipp Kuntz (2015) 'The limits of authoritarian solidarity: The Gulf monarchies and preserving authoritarian rule during the Arab Spring', European Journal of Political Research, Vol. 54 (4), November, pp. 639-54.

Patterson, Ruairi (2013) 'EU Sanctions on Iran: The European Political Context', Middle East Policy. Vol. 20 (1), pp. 131-46. 
Pradhan. Prasanta Kumar (2011) 'The GCC-Iran Conflict and its Strategic Implications for the Gulf Region', Strategic Analysis, Vol. 35 (2), March, pp. 265-76.

PWC (2004) Sustainability Impact Assessment (SIA) of the Negotiations of the Trade Agreements between the European Community and the Countries of the Cooperation Council of the Arab States of the Gulf (GCC), http://trade.ec.europa.eu/doclib/docs/2010/may/tradoc_146134.pdf.

Reuters (2013) 'Greek PM to visit Qatar to discuss investment', 22 January.

Reuters (2015) 'Kuwait's Al Ahli gets Egyptian c.bank nod to buy Piraeus Bank Egypt', 5 August http://www.reuters.com/article/2015/08/05/piraeus-bankma-al-ahli-bank-idUSL5N10G1SN20150805.

Roussanoglou, Nikos (2014) 'The Arab Gulf attracts Greek construction companies', I Kathimerini, 25 October [in Greek].

http://www.kathimerini.gr/789484/article/oikonomia/epixeirhseis/oaravikos-kolpos-elkyei-tis-ellhnikes-kataskeyastikes

Rowley, Emma (2011) 'European Goldfields' Greek gold mining plans get thumbs up', The Telegraph, 8 December

http://www.telegraph.co.uk/finance/newsbysector/industry/mining/8944493 /European-Goldfields-Greek-gold-mining-plans-get-thumbs-up.html.

RT News (2012) 'Controversy over Iran cutting oil flow to Greece', 26 February https://www.rt.com/news/iran-oil-ban-greece-247/

Sambidge, Andy (2014) 'UAE announces \$ 9.75 bn Greek investment project', Arabian Business.com, 6 May http://www.arabianbusiness.com/uaeannounces-9-75bn-greek-investment-project-549269.html.

Shahine, Alaa (2014) 'UAE announces 7-billion euro Athens project with Greece', Bloomberg, 6 May http://www.bloomberg.com/news/articles/201405-06/u-a-e-announces-7-billion-euro-athens-project-with-greece

Al Shayji, Abdullah K. (2014) 'The GCC-US Relationship: A GCC Perspective', Middle East Policy, Vol. XXI (3), Fall, pp. 60-70. 
Smith, Helena (2013) 'Qatari emir buys six Greek islands for a song', The Guardian, 4 March http://www.theguardian.com/world/2013/mar/04/qataremir-buys-six-greek-islands.

Stone, Jon (2015) Why you might have heard some French politicians calling Isis 'Daesh', The Independent, November 16

http://www.independent.co.uk/news/world/europe/why-you-might-have-

heard-some-french-politicians-calling-isis-daesh-a6736291.html

Stratfor (1999) 'Greece Announces Pending Defense Pact with Iran and Armenia', 1 July https://www.stratfor.com/analysis/greece-announcespending-defense-pact-iran-and-armenia

Al-Suwaidi, Abdulla (2011) 'The United Arab Emirates at 40: A Balance Sheet', Middle East Policy, Vol. XVIII (4), Winter, pp. 44-58.

Ta Nea (2015) 'Enas Tsipras stin Teherani', 14 October [in Greek].

Tsakaloyannis, Panos (1983) Greece: Old Problems, New Prospects, in Christopher Hill, ed., National Foreign Policies and European Political Cooperation, London: George Allen and Unwin, 1983, pp. 121-136.

Tziampiris, Aristotle (2015) 'The Israeli-Greek Rapprochement: Stability and Cooperation in the Eastern Mediterranean' in Spyridon N. Litsas and Aristotle Tziampiris, eds, The Eastern Mediterranean in Transition: Multipolarity, Politics and Power, Farnham: Ashgate, pp. 239-53.

Ulrichsen, Kristian Coates (2015) The Gulf States in International Political Economy, London: Palgrave Macmillan.

UNCTAD (2012) Investment Country Profiles: Greece, February, New York: Unctad (http://unctad.org/en/PublicationsLibrary/webdiaeia2012d9 en.pdf).

US Senate (1990) 'Crisis in the Persian Gulf Region: US Policy Options and Implications', Hearings before the Committee on Armed Services, Washington DC: US Government Printing Office, p. 278.

Youngs, R. (2006) Europe and the Middle East: In the Shadow of September 11, Boulder, Co: Lynne Rienner.

Yousef, Deena Kamel and Richard Weiss (2015) 'Gulf Carriers Take Advantage of Greek Airline Void', Bloomberg, 4 July http://skift.com/2015/07/04/gulfcarriers-take-advantage-of-greek-airline-void/ 


\section{Interviews}

Interview 1, Mr Mercourios Karafotias, Former Greek Ambassador to Iran (2005-8) and Iraq (2010-4), Athens.

Interview 2, Mr. Ioannis Christophilis, Former Greek Ambassador to Saudi Arabia (2013-5), Athens.

Interview 3, Mr. Ioannis Metaxas, Greek Ambasador to Qatar, Doha, 5 December 2015.

Interview 4, CEO of Greek Construction Company, Athens, 8 December 2015.

Interview 5, Dr Sotiris Roussos, Former Expert in the Greek Ministry of Foreign Affairs (1996-2003), Athens, 10 October 2015. 



\section{Recent Papers in this Series}

95. Simiti, Marilena, Social Need' or 'Choice'? Greek Civil Society during the Economic Crisis, November 2015

94. Ifantis, Kostas; Triantaphyllou, Dimitrios and Kotelis, Andreas, National Role and Foreign Policy: An Exploratory Study of Greek Elites' Perceptions towards Turkey, August 2015

93. Tsirbas, Yannis and Sotiropoulos, Dimitri A., What do Greek political elites think about Europe and the crisis? An exploratory analysis, July 2015

92. Tsekeris, Charalambos; Kaberis, Nikos and Pinguli, Maria, The Self in Crisis: The Experience of Personal and Social Suffering in Contemporary Greece, June 2015

91. Thomadakis, Stavros B., Growth, Debt and Sovereignty: Prolegomena to the Greek Crisis, May 2015

90. Arapoglou, Vassilis and Gounis, Kostas, Poverty and Homelessness in Athens: Governance and the Rise of an Emergency Model of Social Crisis Management, March 2015

89. Dimelis Sophia, Giotopoulos Ioannis, Louri, Helen, Can firms grow without credit? Evidence from the Euro Area, 2005-2011: A Quantile Panel Analysis, February 2015

88. Panagiotidis, Theodore; Printzis, Panagiotis, On the Macroeconomic Determinants of the Housing Market in Greece: A VECM Approach January 2015

87. Monokroussos, Platon, The Challenge of Restoring Debt Sustainability in a Deep Economic Recession: The case of Greece, October 2014

86. Thomadakis, Stavros; Gounopoulos, Dimitrios; Nounis, Christos and Riginos, Michalis, Financial Innovation and Growth: Listings and IPOs from 1880 to World War II in the Athens Stock Exchange, September 2014

85. Papandreou, Nick, Life in the First Person and the Art of Political Storytelling: The Rhetoric of Andreas Papandreou, May 2014 
84. Kyris, George, Europeanisation and 'Internalised' Conflicts:

The Case of Cyprus, April 2014

83. Christodoulakis, Nicos, The Conflict Trap in the Greek Civil War 19461949: An economic approach, March 2014

82. Simiti, Marilena, Rage and Protest: The case of the Greek Indignant movement, February 2014

81. Knight, Daniel $\mathbf{M}$, A Critical Perspective on Economy, Modernity and Temporality in Contemporary Greece through the Prism of Energy Practice, January 2014

80. Monastiriotis, Vassilis and Martelli, Angelo, Beyond Rising Unemployment: Unemployment Risk Crisis and Regional Adjustments in Greece, December 2013.

79. Apergis, Nicholas and Cooray, Arusha, New Evidence on the Remedies of the Greek Sovereign Debt Problem, November 2013

78. Dergiades, Theologos, Milas, Costas and Panagiotidis, Theodore, Tweets, Google Trends and Sovereign Spreads in the GIIPS, October 2013

77. Marangudakis, Manussos, Rontos, Kostas and Xenitidou, Maria, State Crisis and Civil Consciousness in Greece, October 2013

Online papers from the Hellenic Observatory

All GreeSE Papers are freely available for download at

http://www.Ise.ac.uk/europeanInstitute/research/hellenicObservatory/pubs/ GreeSE.aspx

Papers from past series published by the Hellenic Observatory are available at http://www.Ise.ac.uk/europeanInstitute/research/hellenicObservatory/pubs/ DP oldseries.aspx 